\title{
The composition of mixed-species flocks of birds in and around Chitwan National Park, Nepal
}

Kamal Raj Gosai ${ }^{1,2}$ and Eben Goodale ${ }^{1 *}$ (D)

\begin{abstract}
Background: Mixed-species flocks (MSFs) have been well sampled in the South Asia, but there has been as yet surprisingly little work on MSFs of Nepal, despite a diverse and well-studied avifauna. We surveyed MSFs in two forest types in and around the Important Bird Area of Chitwan National Park in Nepal, between 150 and 800 m a.s.l., to provide a first description of the composition of MSFs in this area. We also aimed to understand which species should be considered 'nuclear species', important to forming MSFs or leading them forward.

Results: In total, we collected records on 222 MSFs that included 100 species, and 6097 individuals. The MSFs were similar to worldwide patterns in being dominated by leaf-gleaning, non-terrestrial insectivores. However, the MSFs were more dominated by canopy species than usual, and did not have a clear gregarious, understory leading species. Rather drongos (Family Dicruridae) and minivets (Family Campephagidae, Genus Pericrocotus) acted as leaders, and a cluster analysis of composition showed one group of large body size MSFs particularly characterized by the presence of the Greater Racket-tailed Drongo (Dicrurus paradiseus).
\end{abstract}

Conclusions: Drongos are known to provide both costs and benefits to other flock participants: they are aggressive birds that can steal food, and manipulate other species with their vocalizations, but at the same time they are 'sentinel species' that produce information about predation risk other species can use. This study demonstrates that drongos can be considered nuclear species for some types of MSFs, despite the potential costs of their presence. MSFs led by sentinel species thus may form in Asia, as well as in the Neotropics.

Keywords: Bird community ecology, Dicruridae, Keystone species, Mixed-species flocks, Species interactions

\section{Background}

Of all vertebrate animals, birds are most likely to group and move together with other species (Morse et al. 1977; Goodale et al. 2017). Mixed-species flocks of birds (MSFs) reach their peak of diversity in forested habitat, where they are found, year-round in the tropics, and in migration and winter in temperate regions (Greenberg 2000; Goodale et al. 2017). Forest MSFs have been

\footnotetext{
*Correspondence: ebengoodale@gxu.edu.cn

${ }^{1}$ Guangxi Key Laboratory of Forest Ecology and Conservation, College of Forestry, Guangxi University, Nanning 530004, China
}

Full list of author information is available at the end of the article described on all continents except Antarctica, with at least 170 descriptive studies over a century of research (Zou et al. 2018). Participation in MSFs helps dilute predation risk (Beauchamp 2014), and increase foraging efficiency without increasing competition as much as monospecific flocks (Sridhar et al. 2009; Goodale et al. 2017). However, mixed-species flocking may also have costs, including that species may have to move at speeds or in locations that are not optimal for them (Hutto 1988; Darrah and Smith 2013).

A frequent observation about MSFs is that some 'nuclear' species are more important than others to their formation or maintenance, and tend to lead them original author(s) and the source, provide a link to the Creative Commons licence, and indicate if changes were made. The images or other third party material in this article are included in the article's Creative Commons licence, unless indicated otherwise in a credit line to the material. If material is not included in the article's Creative Commons licence and your intended use is not permitted by statutory regulation or exceeds the permitted use, you will need to obtain permission directly from the copyright holder. To view a copy of this licence, visit http://creativecommons.org/licenses/by/4.0/. The Creative Commons Public Domain Dedication waiver (http://creativeco mmons.org/publicdomain/zero/1.0/) applies to the data made available in this article, unless otherwise stated in a credit line to the data. 
(Moynihan 1962; Zou et al. 2018). These nuclear species are keystone species for their communities: essential to their functioning and conservation (Mills et al. 1993). Nuclear species tend to be gregarious and to engage in conspicuous calling and otherwise active behavior (Hutto 1994; Goodale and Beauchamp 2010; Pagani-Nunez et al. 2018). Because they have an important conspecific audience in MSFs, which may include kin or mates, it is thought these species are likely to produce costly information such as alarm calls (Goodale et al. 2020).

However, whether a species is a nuclear species is not necessarily black-and-white. In some systems, for example, there are 'secondary' leaders that appear to gain importance when the primary nuclear species is absent (Diamond 1987; Weeks et al. 2020), whereas in other systems there may be several redundant nuclear species (Jones and Robinson 2021). Another complex issue involves a 'sentinel species', one that is particularly vigilant about predation risk, such as drongos (Family Dicruridae) in Asia (Goodale et al. 2020), and whether such a species should be considered nuclear or not. Although drongos make alarm calls to which other species respond, drongos can manipulate other species with false alarms (Flower et al. 2014), attract other species towards MSFs from which they are benefitted (Goodale and Kotagama 2006), and even kleptoparasitize other species (King and Rappole 2001a). It is not clear whether a bird that gives such a complex mix of benefits and costs should be considered a nuclear species, and thus it is necessary to search for more evidence of whether drongos are able to lead MSF systems.

There have been many MSF studies in the southern regions of the South Asia (specifically the Western Ghats and Sri Lanka; Goodale et al. 2009), and some systems have been described in Northeastern India (Srinivasan et al. 2012) and central Myanmar (King and Rappole 2001b). However, to our knowledge there have been no formal descriptions of MSFs in Nepal. This is despite an exceptionally rich avifauna of 887 species, a large ornithological literature, and a strong bird conservation ethos and community (Inskipp et al. 2016; Baral et al. 2018). As an introductory study, we initially aimed to describe MSFs inside and around Chitwan National Park, Nepal's oldest national park and an Important Bird Area for the country (Inksipp et al. 2016), surveying the two most important forest types of the areas (CNP 2015). Preliminary observations, however, suggested that usual gregarious nuclear species were not common, and so we refined our goals to include investigating the leadership of MSFs and especially the role of drongos.

\section{Methods}

\section{Study site}

Chitwan National Park (CNP; $27^{\circ} 16^{\prime}-27^{\circ} 42^{\prime}$ N, $83^{\circ} 50^{\prime}-$ $84^{\circ} 46^{\prime}$ E, elevation $150-815 \mathrm{~m}$ a.s.l., Fig. 1) was established in 1973, and has been documented to provide habitat for 643 species of birds. The $953 \mathrm{~km}^{2}$ park has an additional buffer zone of $729 \mathrm{~km}^{2}$ and is adjacent to other forested areas such as Barandabhar Forest and Kumroj Community Forest (NTNC-BCC and CNP 2020). This larger area, in which we worked, includes the Narayani, Rapti and Reu rivers and their many tributaries. The climate of the region is tropical and subtropical, with a strong summer monsoon; average temperature ranges from $8{ }^{\circ} \mathrm{C}$ to $35^{\circ} \mathrm{C}$, and mean annual rainfall is $\sim 2600 \mathrm{~mm}$ (CNP 2015).

We concentrated on sampling two habitats: Sal Forest (SF) and riverine forest (RF). SF is the most common forest type of the park, covering $70 \%$ of its area. It is dominated by Sal (Shorea robusta), intermixed with Asna (Terminalia alata), Barro (T. bellerica), Bhalayo (Semecarpus anacardium), Karam (Adina cardifolia), Kutmero (Litsea monipetala), and Tantari (Dillenia pentagyna) (Thapa 2011; Baral et al. 2020), with sparse understory ground cover (Lehmkuhl 1994). In contrast, RF is not very common ( $\sim 7 \%$ of the area), but is structurally different, having higher density of trees per hectare, basal area, and tree species richness than SF (Engstrom et al. 2020), and floristically distinct, dominated by Vellar (Trevia nudiflora), Khayar (Acacia catechu), Sissoo (Dalbergia sisso) and Simal (Bombax ceiba). Other habitats of the park are composed of grasslands or wetlands and would not be expected to have forest bird flocks, as grassland and wetland flock systems are very distinct from those of forest (Goodale et al. 2017).

\section{MSF survey}

As part of a larger study on the flocking species the Greater Necklaced Laughingthrush (Garrulax pectoralis) and the Lesser Necklaced Laughingthrush (Garrulax monileger), we aimed to characterize the composition and organization of MSFs of the region and the two habitats. Field studies were conducted from October 2019 to January 2020. We walked dirt roads and footpaths in the park and its surroundings, between 07:30-12:00 $\mathrm{h}$ and 14:30-17:30 $\mathrm{h}$ and avoided revisiting the same roads, with the objective of sampling as many parts of the study area as possible. An MSF was defined as a group of birds moving in the same direction for more than five minutes (Goodale et al. 2009), and was observed from one point for $13.0 \pm 8.2$ (mean \pm standard deviation [SD]) $\mathrm{min}$ on average, and for a maximum of $30 \mathrm{~min}$. All species seen as moving with the MSF at any one moment in time were 


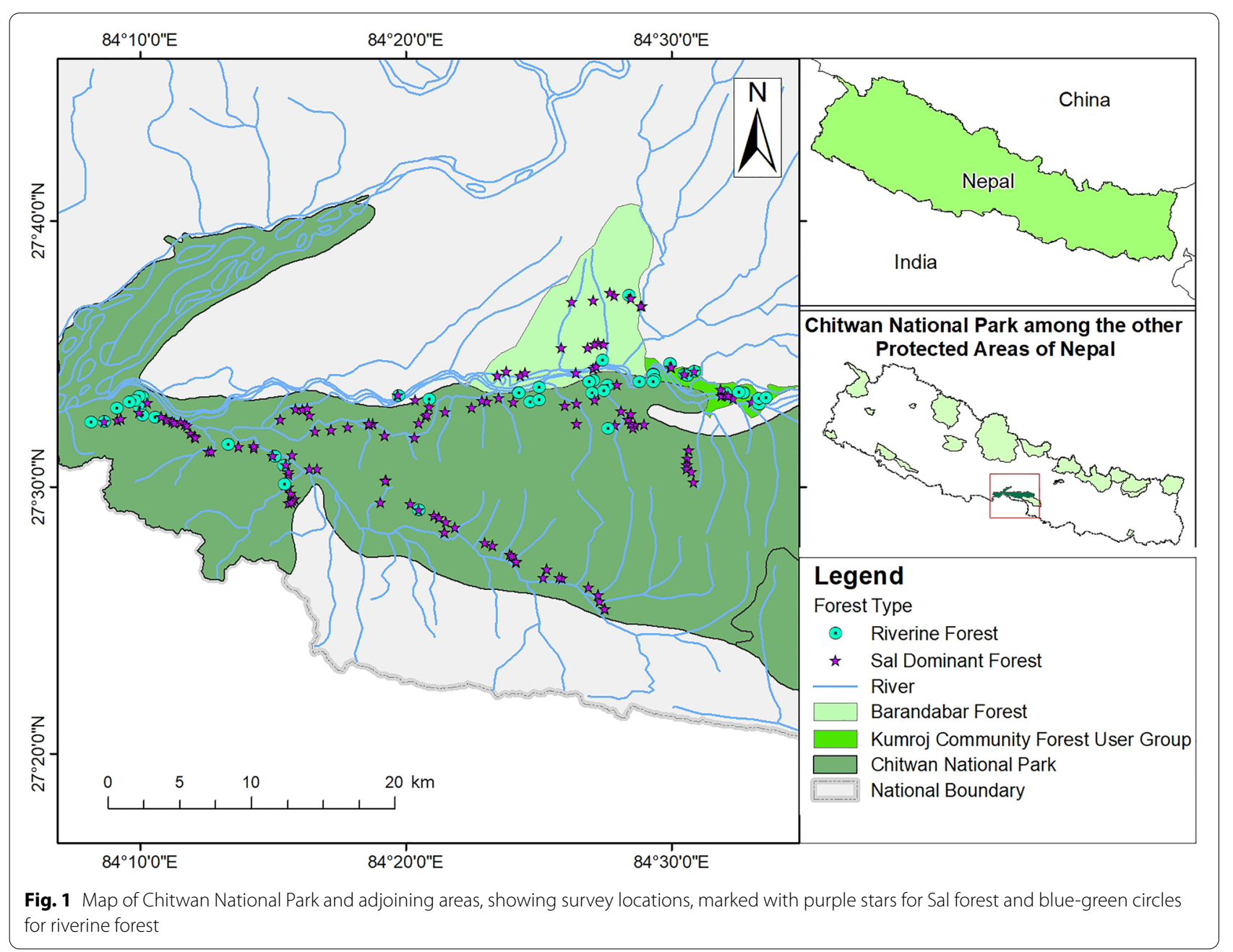

included in its composition. When a species was seen foraging, its vertical strata was also recorded visually, as terrestrial, understory (bottom third of forest height), midstory (middle third) or canopy (topmost third). We also noted the order that species crossed gaps (trails, open water, or forest gaps), making only one observation per MSF. All observations were made by one observer (KRG). Taxonomy follows Grimmett et al. (2016).

For the analysis, we classified species by their traits, using data from the published literature, as well as from the field. Birds were categorized as to their diet (carnivores, frugivores [including granivores], insectivores, nectarivores, omnivores), using data from Grimmett et al. (2016) and the Birds of the World (BOW; https:// birdsoftheworld.org/bow/home). Insectivores and omnivores that consume a lot of insects were further classified into different foraging techniques (gleaning, probing, sallying; Remsen and Robinson 1990). Bird size was categorized as small (less than $10 \mathrm{~cm}$ head to tail), medium $(11-20 \mathrm{~cm})$ and large (above $20 \mathrm{~cm}$ ), and used the same data sources as diet. We categorized species as to their abundance (regular, common, uncommon and rare; categories follow Machado [1999]), and migration ecology (resident and migrant, including altitudinal migrants), based on regional studies of the park's avifauna (NTNCBCC and CNP 2020). Vertical stratification (understory, midstory, canopy, and 'all levels' [there was no clear majority in one vertical strata]) came from field data. As data were heteroschedastic, we used Welch's T-tests to compare the characteristics of MSFs between the two habitats. Mean values are shown \pm SD.

To identify MSF types, we used hierarchical cluster analysis with Ward's minimum variance method on a matrix of species presence and absence (e.g., King and Rappole 2001b; Srinivasan et al. 2012). In order to characterize MSFs, we calculated the mean body size of all the species in an MSF, and then categorized MSFs into those with large, medium and small mean body sizes using the same thresholds of size as above. We also categorized the MSFs into the dominant vertical strata of 
the species in them. We then used Fisher Exact Tests to determine whether different characteristics were spread non-randomly among clusters. We also asked through Fisher Tests whether certain families or species were over-represented in one cluster more than the others. $P$-values $<0.05$ were considered significant.

\section{Results}

\section{MSF size and composition}

During the study period, we encountered a total of 222 MSFs (162 in SF and 60 in RF), including 100 species (93 species in SF, 75 in RF) and 6097 individuals (4509 in SF, 1588 in RF). The mean species richness of MSFs was $9.5 \pm 3.6$, and the mean number of individuals was $27.6 \pm 15.8$. There was no difference between the SF and RF habitats in MSF species richness, the number of individuals, or MSF Shannon-Wiener diversity ( $t$-values $<0.72, P$-values $>0.48$ ).

Eighteen species were regular species in MSFs (seen in $>25 \%$ of MSFs in at least one habitat; Table 1), and of these all but one (Greenish Warbler Phylloscopus trochiloides) was a resident; 16 were insectivores. Likewise, of all the species observed in MSFs (see Additional file 1: Table S1 for a full list), $88 \%$ were residents, and $81 \%$ were insectivores, with the next most common category being frugivores at $11 \%$. Among the insectivores, gleaners (63\%) represented the majority, with salliers next most frequent at $23.5 \%$. When considering vertical stratification, species that inhabited the canopy were the most common (42\%), with understory (26\%) and midstory (23\%) species about equally represented.

We also encountered 35 species that never participated in MSFs in the two forest types, 32 in SF and 21 in RF (Additional file 1: Table S2). Here 46\% were frugivores and insectivores was the next most common group at $37 \%$. Non-flocking species were significantly less likely to be insectivores than flocking ones (Fisher's Exact Test, $P<0.0001$ ).

Hierarchical clustering divided the 222 MSFs into three main clusters (Fig. 2). These clusters were distinguishable in their characteristics with Cluster 1 having MSFs with large mean body sizes more often $(58 / 74,78 \%)$ than the two other clusters (84/148, 57\%; Fisher's Exact Test, $P=0.0018$ ). However, the clusters did not differ as to

Table 1 Those species seen in more than 25\% of either Sal forest (SF, $n=161)$ or riverine forest (RF, $n=61)$ MSFs

\begin{tabular}{|c|c|c|c|c|c|c|c|}
\hline \multirow[t]{2}{*}{ Species } & \multicolumn{2}{|c|}{ Occurrence } & \multirow[t]{2}{*}{ FG } & \multirow[t]{2}{*}{ FM } & \multirow[t]{2}{*}{ VS } & \multirow[t]{2}{*}{ MB } & \multirow{2}{*}{$\begin{array}{l}\text { Mean No. of } \\
\text { individuals } \pm S D\end{array}$} \\
\hline & SF & RF & & & & & \\
\hline Scarlet Minivet (Pericrocotus speciosus) & 87 & 22 & 1 & G & Can & $\mathrm{R}$ & $5.5 \pm 5.4$ \\
\hline Black Hooded Oriole (Oriolus xanthornus) & 73 & 28 & $\mathrm{~F}$ & G & Can & $\mathrm{R}$ & $1.1 \pm 0.6$ \\
\hline Greater Racket Tailed Drongo (Dicrurus paradiseus) & 64 & 11 & 1 & $\mathrm{~S}$ & Ms & $\mathrm{R}$ & $1.3 \pm 0.6$ \\
\hline Chestnut Bellied Nuthatch (Sitta cinnamoventris) & 51 & 27 & 1 & G & Can & $\mathrm{R}$ & $2.3 \pm 1.5$ \\
\hline Bronzed Drongo (Dicrurus macrocercus) & 51 & 6 & 1 & S & Can & $\mathrm{R}$ & $1.9 \pm 0.7$ \\
\hline Grey Capped Pygmy Woodpecker (Dendrocopos canicapillus) & 49 & 23 & I & $P$ & Can & $\mathrm{R}$ & $1.8 \pm 0.7$ \\
\hline Jungle Babbler (Turdoides striata) & 47 & 10 & 1 & G & Ms & $\mathrm{R}$ & $9.9 \pm 4.3$ \\
\hline Great Tit (Parus major) & 45 & 15 & 1 & G & Ms & $\mathrm{R}$ & $1.7 \pm 1.1$ \\
\hline Greenish Warbler (Phylloscopus trochiloides) & 43 & 18 & 1 & G & All & M & $6.7 \pm 4.4$ \\
\hline Grey Headed Woodpecker (Picus canus) & 43 & 6 & I & $P$ & All & $\mathrm{R}$ & $1.3 \pm 0.5$ \\
\hline Large Cuckooshrike (Coracina macei) & 43 & 13 & I & $S$ & Can & $\mathrm{R}$ & $1.1 \pm 0.3$ \\
\hline Velvet Fronted Nuthatch (Sitta frontalis) & 43 & 12 & 1 & G & Can & $\mathrm{R}$ & $1.9 \pm 1.2$ \\
\hline Bar Winged Flycatcher Shrike (Hemipus picatus) & 42 & 7 & 1 & $S$ & Can & $\mathrm{R}$ & $5.3 \pm 6.2$ \\
\hline Fulvous Breasted Woodpecker (Dendrocopos macei) & 41 & 21 & 1 & $P$ & Can & $\mathrm{R}$ & $1.5 \pm 0.8$ \\
\hline Rufous Treepie (Dendrocitta vagabunda) & 41 & 13 & C & G & Ms & $\mathrm{R}$ & $2.0 \pm 0.6$ \\
\hline Common lora (Aegithina tiphia) & 36 & 16 & 1 & G & Can & $\mathrm{R}$ & $3.4 \pm 3.8$ \\
\hline Hume's Leaf Warbler (Phylloscopus humei) & 36 & 16 & 1 & G & All & $\mathrm{R}$ & $1.2 \pm 0.7$ \\
\hline Greater Goldenback (Dinopium benghalense) & 33 & 17 & 1 & $P$ & All & $\mathrm{R}$ & $1.8 \pm 1.1$ \\
\hline
\end{tabular}

Species are ordered by the overall number of MSFs in which they were found. FG feeding guild, FM foraging method, VS vertical strata, MB migratory behavior, $F$ frugivore, I insectivore, $O$ omnivore, $G$ gleaner, $P$ prober, $S$ sallier, All all levels, Can canopy, Ms midstory 

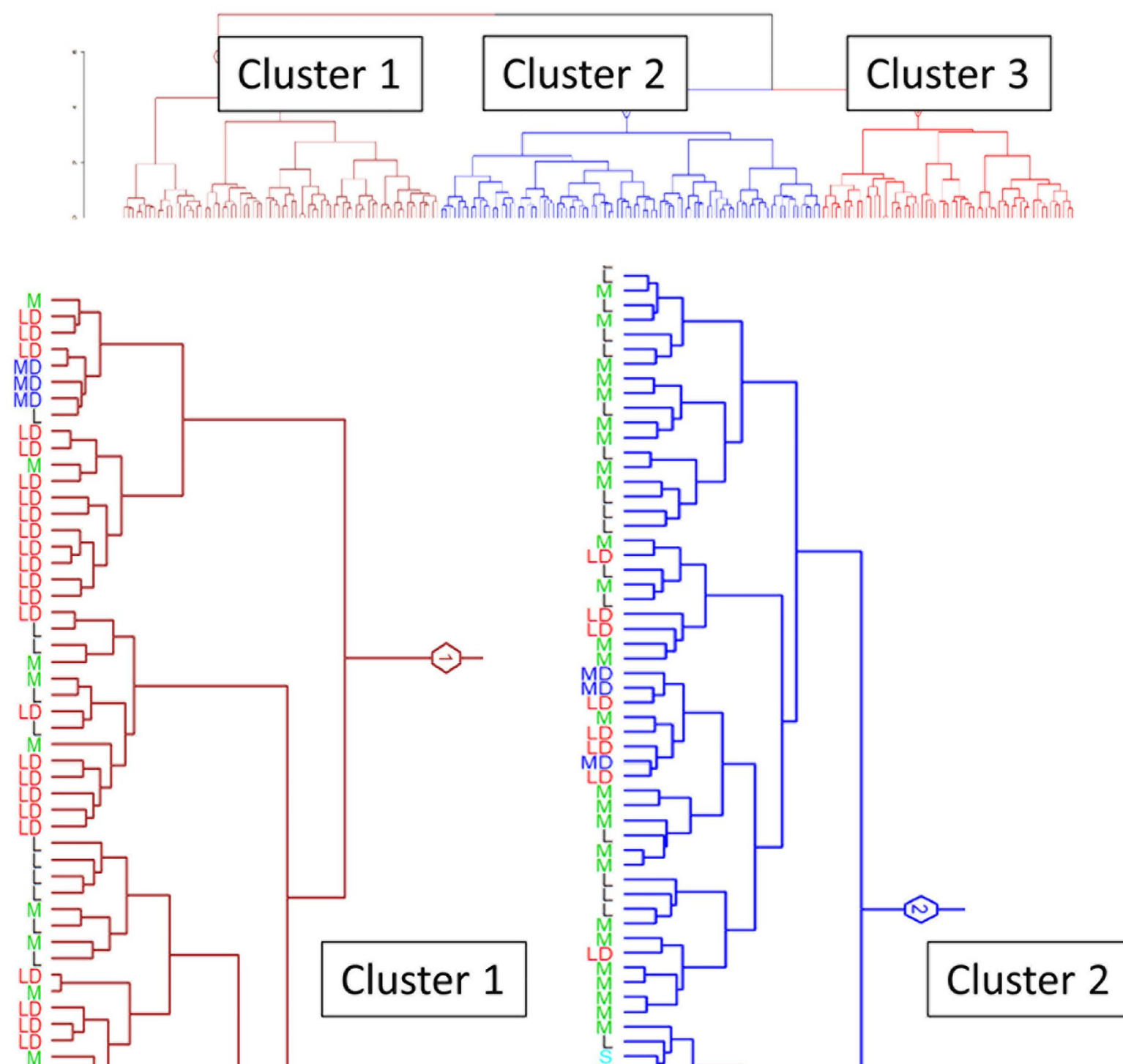

$M=$

$M \square$

LD

च

LD

LD

LD

[D

$M$

LD

LD

$\stackrel{L}{M} \square$

LD

吅

LD $\square$

Cluster 1

$\mathrm{M}$

三

$M=$

M

닉

M

三

$M=$

M

M

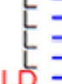

L

七

닌

$=$

D

LO

Fig. 2 (See legend on previous page.) 
their inclusion of species of different diets, vertical strata or habitats (SF vs. RF). Composition also differed among clusters. Cluster 1 had more Dicruridae than in other two clusters (48/74, 65\% vs. 74/148, 50\%; Fisher's Exact Test, $P=0.04)$, and specifically the Greater Racket-tailed Drongo (39/74, 53\%, vs. 34/148, 23\%; Fisher's Exact Test, $P<0.0001)$. Cluster 2 had more Phylloscopidae than the other two clusters $(51 / 89,57 \%$ vs. 39/133, 29\%; Fisher's Exact Test, $P<0.0001)$.

\section{Leadership}

We recorded a movement across a gap for 61 of the 222 MSF observations, only taking one observation per MSF. Greater Racket-tailed Drongo led the most MSFs in both habitats (Table 2). Scarlet Minivet (Pericrocotus flammeus), Bronzed Drongo (Dicrurus aeneus), Spangle Drongo (Dicurus hottentotus) and Bar-winged Flycatcher Shrike (Hemipus picatus) also led MSFs. Some species not only did not lead many MSFs but were consistently seen towards the end of the MSFs, especially six species of woodpeckers.

\section{Discussion}

\section{MSF size and composition}

The Chitwan MSFs that we described are similar to terrestrial forest MSFs globally in that the participants are mostly insectivorous (Powell 1985; Goodale et al. 2017), and not terrestrial (Thiollay 1999). They are also dominated by leaf-gleaning species. Their movement through the vegetation disturbs insects that a group of sallying species like drongos take advantage of (Satischandra et al. 2007; Sridhar and Shanker 2014).

The Chitwan MSFs also have some patterns that appear widespread in Asia. There were a significant number of gregarious species, so that there were more than three times the number of individuals in an average MSF than the number of species. A high number of individuals per MSF has been seen as a characteristic of MSFs of South Asia (Goodale et al. 2009), East Asia (Goodale et al. 2015), and Melanesia (Diamond 1987; Weeks et al. 2017,
2020), due to the presence of highly gregarious nuclear species or secondary leaders. In contrast, MSFs of the Neotropics often include only one or two individuals of most species (Powell 1985). The low number of migrants in MSFs seems to be fairly widespread in South Asia (Goodale et al. 2009); in contrast, some areas of the neotropics have MSFs that are dominated by migrants (e.g., Hutto 1987). The overall picture here is thus that MSFs in different parts of the world with distinct evolutionary histories can show quite different features.

Composition wise, these MSFs are dominated by birds of the canopy (e.g., minivets (Genus Pericrocotus, Family Campephagidae), and ioras (Family Aegithinidae). This is reminiscent of certain MSF types that have been described in Northeast India (the 'canopy' cluster of Srinivasan et al. 2012) and Myanmar (the 'cuckooshrike' cluster of King and Rappole 2001b). Similar MSFs with minivets have been described as far away as peninsular Malaysia (McClure 1967). The clustering result suggests that there may be separate MSF types in the region that are segregated by size, a result also found in other studies in the region (King and Rappole 2001b; Srinivasan et al. 2012). Both meta-analyses (Sridhar et al. 2012) and field studies (Mammides et al. 2018) have shown the birds tend to associate in MSFs with other species of the same body size.

One of our questions entering this study was whether there would be a difference between Sal and Riverine forests habitat types, since the vegetation is structurally and floristically distinct (Lehmkuhl 1994; Thapa 2011; Engstrom et al. 2020). However, we found that MSFs in the two habitats were highly similar, with no significant differences in MSF size and composition. Likewise, Engstrom et al. (2020) found no significant differences in bird species richness between the two habitats. Engstrom et al. (2020) did find that some common species like Pale-chinned Flycatcher (Cyornis poliogenys), Black Bulbul (Hypsipetes leucocephalus) and Blue-throated Barbet (Psilopogon asiaticus) were seen only in RF, but these species are not common in MSFs.

Table 2 Leadership during gap crossings

\begin{tabular}{|c|c|c|c|}
\hline \multicolumn{2}{|l|}{ Sal forest } & \multicolumn{2}{|l|}{ Riverine forest } \\
\hline Leader species & $\%$ occasions led $(n=39)$ & Leader species & $\begin{array}{l}\% \text { occasions led } \\
(n=22)\end{array}$ \\
\hline Greater Racket-Tailed Drongo & 35.9 & Greater Racket-Tailed Drongo & 18.2 \\
\hline Scarlet Minivet & 10.3 & Spangled Drongo (Dicrurus bracteatus) & 18.2 \\
\hline Bar-Winged Flycatcher Shrike & 7.7 & Scarlet Minivet & 13.6 \\
\hline Bronzed Drongo & 7.7 & Oriental White Eye (Zosterops palpebrosus) & 13.6 \\
\hline 11 other species & $\leq 2$ leading events & 7 other species & $\leq 2$ leading events \\
\hline
\end{tabular}

Only species that led MSFs at least three times in one of the habitats are listed. For scientific names, see Table 1 


\section{Nuclear species and leadership}

Connected to the dominance of canopy species, these MSFs did not have a dominant gregarious nuclear species in the understory or midstory. In Asia, nuclear species are often of the babbler family, and the ability of their many individuals to forage at a range of heights enables many other species to follow them (Hsieh and Chen 2011). For example, Turdoides genus babblers and Alcippe genus fulvettas lead MSFs in South Asia (Kotagama and Goodale 2004) and East Asia (Zhou et al. 2019), respectively, but here species of these genera were fairly rare $(<30 \%$ of MSFs).

We hypothesize that this lack of gregarious nuclear species provides an opportunity for drongos to lead MSFs. We repeatedly observed drongos perched for a minute or so, sally and catch food, return to the perch, and then fly ahead of the MSF, with the flock eventually following. Drongos were suggested to be nuclear species in an earlier observation in Sri Lanka in an area which the regular Turdoides nuclear species was absent (Perera et al. 2016). However, the observations here are the first we know to show drongos can be the primary leaders for an MSF system. Yet it has already been established that drongos are important to other species in MSFs. Their alarm calls are especially reliable (Goodale and Kotagama 2005a) and are responded to by many species (Goodale and Kotagama 2008). Further, playback of drongos is as attractive as playback of gregarious babblers to other flock participants in Sri Lanka (Goodale and Kotagama 2005b), and drongos also are known to manipulate other species by attracting them with vocal mimicry (Goodale and Kotagama 2006). So, it makes sense that in a system without dominant gregarious species, drongos can turn into the most important nuclear species.

In these observations in Nepal, we also did not see any kleptoparasitism by drongos, but it was clear that they made alarm calls. Hence, perhaps the benefits they give to other species (vigilance) overweigh the costs (kleptoparasitism, behavioral manipulation). We found that one cluster of MSFs was distinguished by the presence of Greater Racket-tailed Drongos, and this cluster was also characterized by larger body size species. These observations suggest that the presence of drongos is important to the composition of flocks and to community assembly in this flock system. The phylogenetic work of Péron (2017) has also suggested that drongos are important to the assembly to MSFs in the Old World: MSFs with drongos were more phylogenetically clustered than those without, perhaps because the drongos give vigilance benefits that compensates for competition between more closely related species.

These observations are significant because it demonstrates that sentinel species-species that are particularly vigilant-can lead MSFs on different continents. The antshrikes (Thamnomanes sp.) have been shown to be especially important to the formation and leadership of Amazonian MSFs (Stotz 1993; Martínez et al. 2018). Like drongos, these species sally for their prey, which makes them particularly vigilant (Munn 1984), and other species listen to their alarm calls (Martínez et al. 2016), although they are capable of making false alarm calls to steal food as do drongos (Munn 1986). Thus drongo- and antshrike- led MSFs seem to be examples of the convergent evolution of similar community organization in bird MSFs with different evolutionary histories.

\section{Conservation implication for birds' studies in Nepal}

In recent years, there has been a greater emphasis on community-wide conservation, trying to conserve the interactions between species. Mixed-species flocks can be part of such a strategy; indeed, nuclear species can be targeted specifically to try to conserve other participants in MSFs (Zou et al. 2018). Nepal has been successful in focusing on its endangered species in conservation studies (Baral et al. 2018). We hope that this small study can be a starting point for more research on the sociality of Nepali birds, and how this factor can be incorporated into the country's strategy for bird conservation.

\section{Supplementary Information}

The online version contains supplementary material available at https://doi. org/10.1186/s40657-021-00292-3.

Additional file 1: Table S1. A list of all species that participated in MSFs during the survey and their traits. Table S2: A list of all species seen during the survey but not in MSFs.

\section{Acknowledgements}

We thank Tikaram Giri for providing insight on the birds of Chitwan National Park and providing warm hospitality in his hotel. We thank Bishnu Mahato, Pushan Mahato, Anish Mahato and Yam Mahato for their assistance in the field, Asst. Prof. Ramesh Sapkota for his support in statistical analysis and Mrs. Neeru Maharjan Gosai for providing moral support to the first author during the entire research period. We also thank Tej Kumar Shrestha, Lumbini Environmental Services Pvt. Ltd., Nepal for providing a working space during the write-up of the manuscript. Three anonymous reviewers provided helpful comments that improved the manuscript.

\section{Authors' contributions}

KRG and EG conceived and designed the study. KRG collected the data and conducted the analysis. KRG and EG wrote the article. Both authors read and approved the final manuscript.

\section{Funding}

The study was supported by a Special Talent Recruitment grant from Guangxi University to EG and a Chinese Government Scholarship to KRG.

Availability of data and materials

The primary datasets are included in the manuscript and supplemental information. 


\section{Declarations}

\section{Ethics approval and consent to participate}

This study was purely observational, without effects on the birds involved. We obtained permission to conduct the research from the Department of National Park and Wildlife Conservation of Nepal, Chitwan National Park, and the authorities of the community forests.

\section{Consent for publication}

Not applicable.

\section{Competing interests}

The authors declare they have no conflicts of interest.

\section{Author details}

${ }^{1}$ Guangxi Key Laboratory of Forest Ecology and Conservation, College of Forestry, Guangxi University, Nanning 530004, China. ${ }^{2}$ Department of Environmental Science, Tri-Chandra Multiple Campus, Tribhuvan University, Ghantaghar, Kathmandu 44600, Nepal.

\section{Received: 24 May 2021 Accepted: 20 October 2021}

Published online: 29 October 2021

\section{References}

Baral S, Neumann M, Basnyat B, Gauli K, Gautam S, Bhandari SK, et al. Form factors of an economically valuable Sal tree (Shorea robusta) of Nepal. Forests. 2020;11:754

Baral HS, Poudyal LP, Acharya R, Tulsi S. Bird conservation in Nepal. In: Dhakal M, Lamichhane D, Ghimire MD, Poudyal A, Uprety Y, Svich T, et al., editors. 25 years of achievements on Biodiversity conservation in Nepal. 1st ed. Kathmandu, Nepal: Environment and Biodiversity Division, Ministry of Forests and Environment (MoFE); 2018. p. 51-5.

Beauchamp G. Social predation: how group living benefits predators and prey. 1st ed. London: Academic Press; 2014.

CNP. Chitwan National Park and its Buffer Zone Management Plan 2013-2017. Kathmandu, Nepal; 2015.

Darrah, Abigail J, Smith KG. Comparison of foraging behaviors and movement patterns of the Wedge-billed Woodcreeper (Glyphorynchus spirurus) traveling alone and in mixed-species flocks in Amazonian Ecuador. Auk. 2013;130:629-36

Diamond J. Flocks of brown and black New Guinea birds: a bicoloured mixedspecies foraging association. Emu. 1987;87:201-11.

Engstrom RT, Edenius L, Thapa TB, Bidari B, Gurung A, Mikusiński G. Bird communities of two forest types in Chitwan Valley, Nepal. Ornithol Sci. 2020;19:29-40.

Flower TP, Gribble M, Ridley AR. Deception by flexible alarm mimicry in an African bird. Science. 2014;344:513-6.

Goodale E, Beauchamp G. The relationship between leadership and gregariousness in mixed-species bird flocks. J Avian Biol. 2010;41:99-103.

Goodale E, Kotagama SW. Alarm calling in Sri Lankan mixed-species bird flocks. Auk. 2005a;122:108-20.

Goodale E, Kotagama SW. Testing the roles of species in mixed-species bird flocks of a Sri Lankan rain forest. J Trop Ecol. 2005b;21:669-76.

Goodale E, Kotagama SW. Vocal mimicry by a passerine bird attracts other species involved in mixed-species flocks. Anim Behav. 2006:72:471-7.

Goodale E, Kotagama SW. Response to conspecific and heterospecific alarm calls in mixed-species bird flocks of a Sri Lankan rainforest. Behav Ecol. 2008;19:887-94

Goodale E, Nizam BZ, Robin VV, Sridhar H, Trivedi P, Kotagama SW, et al. Regional variation in the composition and structure of mixed-species bird flocks in the Western Ghats and Sri Lanka. Curr Sci. 2009;97:648-63.

Goodale E, Ding P, Liu X, Martínez A, Walters M, Robinson SK. The structure of multi-species flocks and their role in the organization of forest bird communities, with special reference to China. Avian Res. 2015:6:14.

Goodale E, Beauchamp G, Ruxton GD. Mixed-species animal groups: behavior, community structure and conservation. London: Academic Press; 2017.
Goodale E, Sridhar H, Sieving KE, Bangal P, Colorado ZGJ, Farine DR, et al. Mixed company: a framework for understanding the composition and organization of mixed-species animal groups. Biol Rev. 2020;95:889-910.

Greenberg R. Birds of many feathers: The formation and structure of mixedspecies flocks of forest birds. In: Booinski S, Garber PA, editors. On the move: how and why animals travel in groups. Chicago: University of Chicago Press; 2000. p. 521-59.

Grimmett R, Inskipp C, Inskipp T, Baral HS. Birds of Nepal. 1st ed. London: Christopher Helm; 2016.

Hsieh $\mathrm{H}$, Chen C-C. Does niche-overlap facilitate mixed-species flocking in birds? J Ornithol. 2011;152:955-63.

Hutto RL. A description of mixed-species insectivorous bird flocks in Western Mexico. Condor. 1987;89:282-92.

Hutto RL. Foraging behavior patterns suggest a possible cost associated with participation in mixed-species bird flocks. Oikos. 1988;51:79.

Hutto RL. The composition and social organization of mixed-species flocks in a tropical deciduous forest in western Mexico. Condor. 1994;96:105-18.

Inskipp C, Baral HS, Phuyal S, Bhatt TR, Khatiwada M, Inskipp T, et al. The status of Nepal's birds: the National Red List Series, vol. 1. London: The Zoological Society of London; 2016

Jones HH, Robinson SK. Vegetation structure drives mixed-species flock interaction strength and nuclear species roles. Behav Ecol. 2021;32:69-81.

King DI, Rappole JH. Kleptoparasitism of laughingthrushes Garrulax by Greater Racket-tailed Drongos Dicrurus paradiseus in Myanmar. Forktail. 2001a;17:121-2.

King DI, Rappole JH. Mixed-species bird flocks in dipterocarp forest in northcentral Burma (Myanmar). Ibis. 2001b;143:380-90.

Kotagama SW, Goodale E. The compositions and spatial organisation of mixedspecies flocks in Sri Lankan rainforests. Forktail. 2004;20:63-70.

Lehmkuhl JF. A classification of subtropical riverine grassland and forest in Chitwan National Park, Nepal. Vegetation. 1994;111:29-43.

Machado CG. Mixed flocks of birds in Atlantic Rain Forest in Serra de Paranapiacaba, southeastern Brazil. Rev Bras Biol. 1999;59:75-85.

Mammides C, Chen J, Goodale UM, Kotagama SW, Goodale E. Measurement of species associations in mixed-species bird flocks across environmental and human disturbance gradients. Ecosphere. 2018;9:e02324.

Martínez AE, Gomez JP, Ponciano JM, Robinson SK. Functional traits, flocking propensity, and perceived predation risk in an Amazonian understory bird community. Am Nat. 2016;187:607-19.

Martínez AE, Parra E, Muellerklein O, Vredenburg VT. Fear-based niche shifts in neotropical birds. Ecology. 2018;99:1338-46.

McClure HE. The composition of mixed species flocks in lowland and submontane forests of Malaya. Wilson Bull. 1967;79:131-55.

Mills LS, Soule ME, Doak DF. The keystone-species concept in ecology and conservation. Bioscience. 1993;43:219-24.

Morse DH. Feeding behavior and predator avoidance in heterospecific groups. Bioscience. 1977:27:332-9.

Moynihan M. The organization and probable evolution of some mixed species flock of neotropical birds. Smithson Misc Collect. 1962;14:1-140.

Munn CA. The behavioral ecology of mixed-species bird flocks in Amazonian Peru. Doctoral dissertation. Princeton: Princeton University; 1984.

Munn CA. Birds that "cry wolf." Nature. 1986;319:143-5.

NTNC-BCC and CNP. A checklist of fauna and flora in and around Chitwan National Park. 1st ed. Chitwan, Nepal: National Trust for Nature Conservation-Biodiversity Conservation Center (NTNC-BCC) and Chitwan National Park (CNP). 2020.

Pagani-Núñez E, Xia X, Beauchamp G, He R, Husson JHD, Liang D, et al. Are vocal characteristics related to leadership patterns in mixed-species bird flocks? J Avian Biol. 2018;49:jav-01674.

Perera MP, Kotagama SW, Goodale E, Kathriarachchi HS. What happens when the nuclear species is absent? Observations of mixed-species bird flocks in the Hiyare Forest Reserve in Sri Lanka. Forktail. 2016:32:96-7.

Péron G. Multicontinental community phylogenetics of avian mixed-species flocks reveal the role of the stability of associations and of kleptoparasitism. Ecography. 2017;40:1267-73.

Powell GVN. Sociobiology and the adaptive significance of interspecific flocks in the Neotropics. Ornithol Monogr. 1985;36:713-32.

Remsen J, Robinson S. A classification scheme for foraging behavior of birds in terrestrial habitats. Stud Avian Biol. 1990;13:144-60. 
Satischandra SHK, Kudavidanage EP, Kotagama SW, Goodale E. The benefits of joining mixed-species flocks for Greater Racket-tailed Drongos Dicrurus paradiseus. Forktail. 2007;23:145-8.

Satischandra SHK, Kodituwakku P, Kotagama SW, Goodale E. Assessing, "false" alarm calls by a drongo (Dicrurus paradiseus) in mixed-species bird flocks. Behav Ecol. 2010;21:396-403.

Sridhar $\mathrm{H}$, Shanker K. Importance of intraspecifically gregarious species in a tropical bird community. Oecologia. 2014;176:763-70.

Sridhar H, Beauchamp G, Shanker K. Why do birds participate in mixed-species foraging flocks? A Large-Scale Synthesis. Anim Behav. 2009;78:337-47.

Sridhar H, Srinivasan U, Askins RA, Canales-Delgadillo JC, Chen CC, Ewert DN, et al. Positive relationships between association strength and phenotypic similarity characterize the assembly of mixed-species bird flocks worldwide. Am Nat. 2012;180:777-90.

Srinivasan U, Raza RH, Quader S. Patterns of species participation across multiple mixed-species flock types in a tropical forest in northeastern India. J Nat Hist. 2012;46:2749-62.

Stotz DF. Geographic variation in species composition of mixed-species flocks in lowland humid forests in Brazil. Pap Avulsos Zool. 1993;38:61-75.

Styring AR, Ickes K. Woodpecker participation in mixed species flocks in peninsular Malaysia. Wilson Bull. 2001;113:342-5.
Thapa TB. Habitat suitability evaluation for leopard (Panthera pardus) using remote sensing and GIS in and around Chitwan National Park, Nepal. Doctoral dissertation. India: Saurahastra University; 2011.

Thiollay JM. Frequency of mixed species flocking in tropical forest birds and correlates of predation risk: an intertropical comparison. J Avian Biol. 1999;30:282-94.

Weeks BC, Naeem S, Winger BM, Cracraft J. New behavioral, ecological, and biogeographic data on the montane avifauna of Kolombangara, Solomon Islands. Wilson J Ornithol. 2017:10:10593-606.

Weeks BC, Diamond J, Sweet PR, Smith C, Scoville G, Zinghite T, Fillardi CE, et al. The relationship between morphology and behavior in mixed-species flocks of island birds. Ecol Evol. 2020;129:676-80.

Winterbottom JM. On woodland bird parties in Northern Rhodesia. Ibis. 1943:85:434-42.

Zhou L, Peabotuwage I, Gu H, Jiang D, Hu G, Jiang A, et al. The response of mixed-species bird flocks to anthropogenic disturbance and elevational variation in southwest China. Condor. 2019;121:1-13.

Zou F, Jones H, Colorado ZGJ, Jiang D, Lee TM, Martínez A, et al. The conservation implications of mixed-species flocking in terrestrial birds, a globallydistributed species interaction network. Biol Conserv. 2018:224:267-76.
Ready to submit your research? Choose BMC and benefit from:

- fast, convenient online submission

- thorough peer review by experienced researchers in your field

- rapid publication on acceptance

- support for research data, including large and complex data types

- gold Open Access which fosters wider collaboration and increased citations

- maximum visibility for your research: over 100M website views per year

At BMC, research is always in progress.

Learn more biomedcentral.com/submissions 